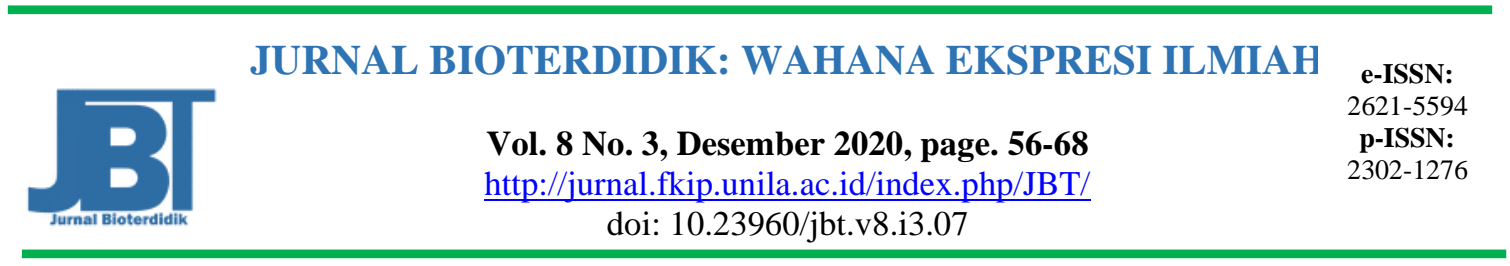

\title{
Uji Mortalitas Ulat Grayak (Spodoptera litura F.) Terhadap Ekstrak Tanaman Lidah Mertua (Sansevieria trifasciata Prain)
}

\author{
Gusthi Ayu Permatasari, Nova Hariani*, Sus Trimurti \\ Laboratorium Ekologi dan Sistematika Hewan, Program Studi Biologi, Fakultas Matematika dan Ilmu \\ Pengetahuan Alam, Universitas Mulawarman \\ *email: nova.ovariani@gmail.com
}

\begin{abstract}
Mortality Test of Grayak Caterpillars (Spodoptera litura F.) Against Extracts of Tongue Plants (Sansevieria trifasciata Prain). The tongue-in-law plant (Sansevieria trifasciata Prain) contains saponins, flavonoids, steroids and triterpenoids which are natural metabolites that have the potential to control agricultural pests such as armyworms (Spodoptera sp.). Therefore, the aim of this study was to determine the mortality and LC50 value for 72 hours of giving in-law tongue plant extract to Spodoptera litura and the length of the life cycle of S. litura in the laboratory. The research method used a completely randomized design (CRD). The extract of the tongue-in-law plant is obtained from the maceration process of the tongue-in-law plant with ethanol and then concentrated using a rotary evaporator until the thick extract is obtained. The results of the research on the ethanol extract of the tongue-in-law plant on the mortality of $S$. litura, found that the highest mortality was $63.6 \%$ at a concentration of 800 ppm and the lowest mortality value was $36.4 \%$ at a concentration of 200 ppm for 72 hours.
\end{abstract}

Keywords: mortality, Sansevieria trifasciata., Spodoptera litura

\begin{abstract}
Abstrak: Uji Mortalitas Ulat Grayak (Spodoptera litura F.) Terhadap Ekstrak Tanaman Lidah Mertua (Sansevieria trifasciata Prain). Tanaman lidah mertua (Sansevieria trifasciata Prain) mengandung saponin, flavonoid, steroid, dan triterpenoid yang merupakan metabolit alami yang berpotensi untuk mengendalikan hama pertanian seperti ulat grayak (Spodoptera sp.). Oleh karena itu, tujuan dari penelitian ini adalah untuk mengetahui mortalitas dan nilai LC50 selama 72 jam pemberian ekstrak tumbuhan lidah mertua terhadap Spodoptera litura dan lamanya siklus hidup S. litura di laboratorium. Metode penelitian menggunakan Rancangan Acak Lengkap (RAL). Ekstrak tumbuhan lidah mertua diperoleh dari proses maserasi tumbuhan lidah mertua dengan etanol kemudian dipekatkan menggunakan rotary evaporator hingga diperoleh ekstrak kental. Hasil penelitian ekstrak etanol tumbuhan lidah mertua terhadap mortalitas S. litura didapatkan mortalitas tertinggi sebesar $63,6 \%$ pada konsentrasi 800 ppm dan nilai mortalitas terendah pada konsentrasi 36,4\%. 200 ppm selama 72 jam.
\end{abstract}

Kata kunci: mortalitas, Sansevieria trifasciata, Spodoptera litura 


\section{PENDAHULUAN}

Hama merupakan kategori organisme yang menyerang dan mengganggu lingkungan hidup manusia bahkan mengakibatkan kerugian dalam segi ekonomi. Kelompok terbesar dari hama berasal dari kelompok serangga dan merupakan hama penting pada sayuran hijau misalnya ulat grayak (Spodoptera sp.) (Haryanti, dkk., 2006). Spodoptera litura (ulat grayak) merupakan hama polifagus yang memiliki siklus hidup holometabola (sempurna) dan termasuk ke dalam ordo lepidoptera sub ordo heterocera, imago dengan ciri-ciri sayap bersisik dan kebanyakan aktivitasnya pada malam hari (Nokturnal). (Fattah dan Ilyas, (2016); Marwoto dan Suharsono (2008). Kerusakan akibat serangan hama ini pada tanaman sayur hijau bervariasi antara 5\% sampai 100\% (Prawesti, 2017).

Pengendalian hama ini masih menggunakan insektisida sintetis, yang menimbulkan dampak negatif terhadap lingkungan (Samsudin, 2008). Untuk mengatasi dampak negatif dari insektisida sintetis perlu dicari alternative lain dengan cara memanfaatkan tumbuhan yang memiliki kandungan metabolit sekunder untuk mengendalikan hama tersebut. Tanaman lidah mertua tergolong tumbuhan succulent yang banyak menyimpan kandungan air serta zat metabolit sekunder. Ekstrak daun lidah mertua mengandung saponin, flavonoid, steroid dan triterpenoid yang merupakan metabolit alami dengan potensi menghambat jamur sehingga diperkirakan juga dapat mengendalikan ulat grayak (Komala, dkk., 2012).

Beberapa metabolit sekunder yang dapat diekstrak dengan etanol adalah flavonoid yang berfungsi sebagai pendenaturasi dan koagulasi protein sehingga merusak sel beberapa spesies serangga (Azmir, et al., 2013), kemudian saponin berfungsi sebagai pengganggu permeabilitas sel yang dapat mengganggu dan merusak jaringan pencernaan serangga (Mien, dkk., 2015). Selain itu, terdapat juga alkaloid dan tannin sebagai antifeedant (penghilang nafsu makan) terhadap mulut serangga (Roy, et al., 2012). Salah satu penelitian tentang metabolit sekunder dari ekstrak lidah mertua tentang toksisitas dan skrining fitokimia dari akar rimpang dan daun lidah mertua didapatkan LC50 $35.22 \mu \mathrm{g} / \mathrm{ml}$ dan $44.49 \mu \mathrm{g} / \mathrm{ml}$ pada Brine shrimp bioassay (Berame, et al., 2017). Sampai saat ini penelitian tentang pengendalian hama grayak dengan insektisida nabati lidah mertua belum pernah dilakukan. Oleh karena itu perlu dilakukan penelitian yang bertujuan untuk mengetahui efek ekstrak tanaman lidah mertua terhadap mortalitas ulat grayak.

\section{METODE}

Penelitian telah dilaksanakan mulai dari bulan Maret sampai Juli 2020. Sampel larva didapatkan dari perkebunan sawi, Desa Purwajaya, Kabupaten Kutai Kartanegara, Kalimantan Timur. Pengujian toksisitas dan mortalitas terhadap ulat grayak (Spodoptera litura) dilaksanakan di Laboratorium Ekologi dan Sistematika Hewan, Fakultas Matematika dan Ilmu Pengetahuan Alam, Universitas Mulawarman.

Alat dari percobaan ini toples ukuran $1 \mathrm{~L}$ sebanyak 20 buah, toples ukuran $16 \mathrm{~L}$ sebanyak 5 buah, 5 buah, plastik, karet, petri dish, spatula, gelas ukur, neraca analitik, kertas tisu, gunting, pipet, pinset, kuas halus, corong buchener, ayakan 60 mesh, neraca analitik, timbangan, kain sifon, kertas saring, rotary evaporator, Hygrometer, baki ukuran 40x20 cm 10 buah, pisau, botol sampel ukuran $200 \mathrm{ml}$ dan blender.

Bahan dari percobaan ini adalah daun dan akar lidah mertua (Sansevieria trifasciata) $2 \mathrm{~kg}$, larutan gula 10\%, Alkohol 96\%, akuades steril, bayam liar, larva Spodoptera litura. 
Penelitian dilakukan menggunakan Rancangan Acak Lengkap (RAL) dengan setiap perlakuan diulang 4 kali dengan 4 perlakuan dan 1 kontrol $(0 \%, 200$ ppm, 400 ppm, 600 ppm, 800 ppm). Pemberian pakan perlakuan ekstrak dilakukan selama 3 hari (3x24 jam) dan pakan diganti dengan yang baru setiap harinya pada waktu yang sama. Setelah 3 hari perlakuan beberapa larva yang masih hidup diberi pakan tanpa ekstrak dengan mengganti pakan setiap hari pada waktu yang sama sampai berubah menjadi pupa. Data yang diambil adalah jumlah larva yang mati, dan perkembangan larva berupa pengamatan morfologi dan panjang dan lebar larva diambil setiap 24 jam untuk data sekunder. Sebagai dasar data primer penentuan LC50 dengan menggunakan analisis probit dan analisis varian dengan program SPSS.

Perbanyakan Hewan Uji. Larva tersebut dipelihara dengan suhu ruang $22-25^{\circ} \mathrm{C}$, serta kelembapan relatif udara 62-96\%. sampai menjadi larva instar III, pakan yang diberikan merupakan bayam segar yang diganti dan dibersihkan dengan kuas hingga larva mencapai pupa. Fase pupa kemudian dipindahkan ke dalam wadah kawat yang dialasi tisu untuk bertelur hingga menjadi imago kemudian diberi pakan larutan gula 10\% yang disemprotkan pada kapas kemudian diberi wadah kecil yang diletakkan di tengah toples, kapas dan air gula disemprotkan setiap harinya hingga bertelur. Telur pada tisu kemudian dipindahkan ke dalam toples saat telur menetas yang diberi pakan bayam hingga jumlah dan umur larva terpenuhi untuk di uji.

Ekstraksi tanaman. Ekstrak lidah mertua dibuat dengan menggunakan metode maserasi atau perendaman dengan pelarut ethanol. Daun dan akar tumbuhan dicuci bersih, daun dipotong kecil-kecil dan dikering anginkan (tanpa terpapar oleh sinar matahari secara langsung), kemudian ditimbang berat awalnya. Setelah kering ditandai dengan berat yang telah konstan, dan dihaluskan kemudian diayak dan ditimbang berat keringnya. Kemudian hasil pemblenderan dimaserasi dalam etanol 96\% dengan perbandingan 1:5.

Perendaman atau proses maserasi dilakukan pada suhu kamar hingga 72 jam, setiap hari diaduk. Setelah 72 jam, hasil maserasi disaring dengan menggunakan corong buchener yang dialasi dengan kertas saring, kemudian maserat diuapkan dengan menggunakan Rotary evaporator sampai dihasilkan ekstrak kental lidah mertua tersebut disimpan di lemari pendingin $\left(10^{\circ} \mathrm{C}\right)$ sampai digunakan untuk proses pengujian. Ekstrak kental selanjutnya akan diencerkan dengan akuades sesuai konsentrasi yang diperlukan dengan rumus berikut:

$$
\mathrm{V}_{1} \times \mathrm{M}_{1}=\mathrm{V}_{2} \times \mathrm{M}_{2}
$$

Keterangan:

$\mathrm{V}_{1}=$ Volume yang dicari

$\mathrm{M}_{1}=$ Konsentrasi awal

$\mathrm{V}_{2}=$ Volume yang diinginkan

$\mathrm{M}_{2}=$ Konsentrasi yang diinginkan

Uji Bioassay. Uji Bioassay dimulai dengan uji pendahuluan dengan konsentrasi yang mengacu hasil penelitian oleh Berame, et al., (2017) kemudian diambil 5 taraf konsentrasi sebagai uji pendahuluan 0 20, 40,60, 80 ppm dengan 10 ekor larva uji. Didapatkan hasil sebagai berikut selama 72 jam pada berturut-turut 5, 2, 5, 4, 8 ekor larva. Percobaan sesungguhnya menggunakan 5 perlakuan dengan konsentrasi pendahuluan dikali kan 10 diharapkan mendapatkan kematian 10-90\% yaitu (0, 200 ppm, 400 ppm, 600 ppm, 800 
ppm). Setiap konsentrasi terdapat 4 ulangan, setiap ulangan terdapat 10 ekor larva yang dibiarkan lapar selama 2 jam. Bayam kemudian dicuci bersih selanjutnya dicelupkan ke dalam ekstrak (berbagai konsentrasi) dengan metode leaf dipping yang direndam selama 10 menit kemudian dikeringkan sampai tidak ada lagi air pada permukaan daun, selanjutnya diberikan sebagai pakan larva selama 3 hari (3x24 jam), diamati setiap hari, setelah 3 hari aplikasi larva yang masih hidup diberi makan bayam tanpa ekstrak.

Data untuk parameter mortalitas dilakukan dengan menghitung jumlah larva yang mati setiap 24 jam setelah aplikasi. Kemudian larva yang masih hidup diberi makan dan diamati jumlah larva yang mati setiap hari pada waktu yang sama selama 3 hari atau 72 jam, larva yang masih hidup dipelihara sampai terbentuk stadia imago dan bertelur. Kemudian untuk parameter perkembangan dilakukan dengan mengamati morfologi dan panjang dan lebar larva setiap hari. Lamanya perkembangan setiap stadia serangga kemudian dicatat.

Analisis Data Primer. Apabila jumlah kematian larva kontrol antara 5\% sampai dengan 20\% maka dilakukan koreksi data dengan rumus Abbot sebagai berikut:

Keterangan:

$$
p=\frac{p o-p c}{100-p c} x 100 \%
$$

$\mathrm{P}=$ Persentase banyaknya serangga yang mati setelah dikoreksi

Po =Persentase banyaknya serangga yang mati karena perlakuan insektisida alami

$\mathrm{Pc}=$ Persentase banyaknya serangga yang mati pada kontrol (mortalitas alami).

\section{HASIL DAN PEMBAHASAN}

Hasil Uji Mortalitas Ulat Grayak (Spodoptera litura F.) Terhadap Ekstrak Lidah Mertua (Sansevieria trifasciata Prain). Hasil penelitian tentang uji kematian (mortalitas) larva terhadap ekstrak tanaman lidah mertua (Sanseviera trifasciata) pada masing-masing konsentrasi pada 24 jam setelah pemaparan dapat dilihat pada Tabel 1 setiap konsentrasi menunjukkan mortalitas yang berbeda, makin tinggi konsentrasi ekstrak maka makin tinggi persentase kematian larva. Angka mortalitas ini menggambarkan bahwa setiap konsentrasi dapat membunuh larva S. litura.

Dari Tabel 1 dapat diketahui bahwa setiap konsentrasi memiliki persentase mortalitas yang berbeda sesuai dengan tingkat konsentrasi. Tingkat kematian ditemukan mulai dari konsentrasi terkecil hingga terbesar berbanding lurus dengan tingkat konsentrasi. Pengamatan 24 jam, persentase mortalitas tertinggi ditemukan pada konsentrasi tertinggi 800 ppm yaitu $36,84 \%$, adanya mortalitas dari setiap konsentrasi yang diuji menunjukkan bahwa ekstrak lidah mertua bersifat toksik terhadap larva grayak. Mortalitas terendah ditemukan pada konsentrasi 200 ppm dengan persentase 10,53\%. Persentase mortalitas larva $S$. litura terhadap ekstrak tanaman lidah mertua yang didapatkan pada penelitian ini, lebih baik jika dibandingkan dengan ekstrak tumbuhan Sidondo (Vitex negundo) terhadap larva S.exigua selama 24 jam dalam penelitian Rifai, dkk., (2016) dengan menggunakan 7500 ppm $(0,75 \%)$ mortalitas $30 \%$.

Pengamatan selama 48 jam menunjukkan tanda yang sama bahwa kenaikan konsentrasi juga menyebabkan kenaikan persentase mortalitas serangga uji. 
Tabel 1. Persentase mortalitas S. litura F. Terhadap Ekstrak Tanaman Lidah Mertua ( $S$. trifasciata) selama 24 jam, 48 Jam dan 72 jam

\begin{tabular}{ccccc}
\hline No. & Konsentrasi & \multicolumn{3}{c}{ Mortalitas(\%) } \\
\cline { 3 - 5 } & Ekstrak & 24 jam & 48 jam & 72 jam \\
\hline $\mathbf{1}$ & Kontrol & 0 & 0 & 0 \\
\hline $\mathbf{2}$ & $200 \mathrm{ppm}$ & 10,53 & 9,09 & 36,4 \\
\hline 3. & $400 \mathrm{ppm}$ & 23,68 & 15,15 & 42,4 \\
\hline $\mathbf{4 .}$ & $600 \mathrm{ppm}$ & 26,32 & 21,21 & 51,5 \\
\hline $\mathbf{5 .}$ & $800 \mathrm{ppm}$ & 36,84 & 42,42 & 63,6 \\
\hline
\end{tabular}

Persentase mortalitas tertinggi ditemukan pada konsentrasi 800 ppm dengan mortalitas $42,4 \%$, kemudian dilanjutkan dengan konsentrasi 600 ppm dengan mortalitas 21,21\%, selanjutnya konsentrasi 400 ppm persentase mortalitas $15,15 \%$, kemudian yang terakhir atau konsentrasi yang memiliki kematian larva terendah konsentrasi 200 ppm dengan mortalitas $9,09 \%$.

Tabel 2. Nilai LC 50,90 berdasarkan persentase mortalitas $S$. litura F. terhadap ekstrak tanaman lidah mertua (S. trifasciata) selama 72 jam

\begin{tabular}{rccc}
\hline LC & Konsentrasi & $\begin{array}{c}\text { Minimum } \\
(\mathrm{ppm})\end{array}$ & Maksimum \\
\cline { 2 - 4 } & & 460,5 & 707,3 \\
\hline $50 \%$ & 562,9 & 961,0 & 1675,0 \\
\hline $90 \%$ & 1186,2 &
\end{tabular}

Tingkat toksisitas ini tergolong lebih baik jika dibandingkan dengan Mirabilis jalapa terhadap S.litura selama 48 jam dalam penelitian Risqa (2018), dimana didapatkan persentase mortalitas 37,5 \% pada taraf konsentrasi yang lebih tinggi yaitu 0,4\% (4000 ppm) jika dibandingkan dengan konsentrasi 800 ppm yang digunakan dalam penelitian ini.

Mortalitas larva $S$. litura setelah terpapar ekstrak lidah mertua setelah 72 jam yang terdapat pada Tabel 1, menunjukkan hal yang sama bahwa laju mortalitas berbanding lurus dengan kenaikan konsentrasi ekstrak. Mortalitas tertinggi tetap ditemukan pada konsentrasi 800 ppm dengan persentase 63,6\%. Kemudian dilanjutkan dengan konsentrasi 600 ppm dengan persentase mortalitas 51,5\%. Selanjutnya konsentrasi $400 \mathrm{ppm}$ dengan persentase mortalitas 42,4\%. Terakhir konsentrasi yang memiliki kematian larva terendah ditemukan pada konsentrasi 200 ppm dengan persentase mortalitas 36,4\%. Tingkat toksisitas ini masih lebih baik jika dibandingkan dengan penelitian Djunaedy dan Anggrahini (2018), ekstrak daun mahoni (Swietenia mahagoni Jacq) terhadap mortalitas ulat grayak (S. litura F.) sebanyak 66,6 \% pada taraf konsentrasi 0,6\% (6000 ppm) yang lebih tinggi dibandingkan dengan $800 \mathrm{ppm}$, dengan waktu yang yang lebih lama yaitu 144 jam.

Konsentrasi ekstrak lidah mertua 800 ppm pada pengamatan 24 jam, 48 jam dan 72 jam dapat membunuh larva lebih banyak dibandingkan dengan hasil penelitian yang dilakukan Rifai, dkk., (2016); Risqa, (2018) serta Djunaidi dan Anggrahini (2018) yang umumnya menggunakan ekstrak tumbuhan dengan konsentrasi yang jauh lebih tinggi. Persentase mortalitas larva S. litura terhadap ekstrak lidah mertua, lebih tinggi atau lebih toksik. 
Berdasarkan analisis probit menggunakan aplikasi SPSS, dapat diketahui bahwa hasil LC $\mathrm{C}_{50}$ selama 72 jam didapatkan nilai sebesar 562,9 ppm dan LC 90 selama 72 jam senilai 1186,2 ppm (Tabel 2). Hal ini berarti bahwa konsentrasi ekstrak tanaman lidah mertua sebanyak 562,9 ppm dapat membunuh 50\% populasi larva grayak dan konsentrasi 1.186,2 ppm dapat membunuh $90 \%$ populasi larva grayak pada skala laboratorium. Nilai $\mathrm{LC}_{50,72 \mathrm{jam}}$ yang didapat pada penelitian ini agak lebih tinggi dibandingkan dengan yang dilaporkan Syahputra, dkk., (2004), bahwa nilai $\mathrm{LC}_{50}$ ekstrak getah kulit batang Calophyllum soulattri memiliki LC L $_{50}$ 0,04\% (400ppm) terhadap larva Crocidolomia pavonana, toksisitas yang kurang lebih sama kuat dengan ekstrak tanaman lidah mertua yang didapatkan yaitu $562 \mathrm{ppm}$. Tetapi, lebih toksik jika dibandingkan dengan hasil penelitian yang dilaporkan Hasyim, $d k k$., (2019), tentang LC $_{50,72}$ ekstrak tanaman suren (Toona sureni) terhadap S. exigua dengan nilai LC $50,72 \mathrm{jam}$ sebesar $6542 \mathrm{ppm}$, Nihayah, dkk., (2016) menjelaskan bahwa dengan matinya ulat grayak sebanyak 50\% maka populasi ulat grayak juga berkurang sebanyak 50\%, sehingga dapat mengurangi kerugian yang diakibatkan serangan ulat grayak. Ekstrak yang mempunyai nilai $\mathrm{LC}_{50}$ rendah merupakan ekstrak yang lebih baik dibandingkan dengan yang mempunyai nilai $\mathrm{LC}_{50}$ tinggi. Artinya konsentrasi ekstrak rendah tetapi dapat mematikan ulat grayak dalam jumlah yang besar sehingga baik untuk dijadikan pestisida nabati. Sebaliknya, jika sifat toksisitasnya rendah maka konsentrasi yang dibutuhkan harus lebih tinggi sehingga tidak efektif untuk dijadikan sebagai pestisida nabati.

Perkembangan Siklus Hidup Ulat Grayak. Pada Tabel 3 Perkembangbiakan S. litura di laboratorium rata-rata memerlukan waktu sekitar 35 sampai 38 hari dalam satu siklus hidup. Imago betina meletakkan telur secara bertumpuk pada permukaan tisu, satu tumpukan telur tersebut disebut kluster, dalam satu kluster terdiri atas kurang lebih 350 butir dari satu imago betina dapat menghasilkan 1-2 kluster. Kluster telur ditutupi oleh rambut yang halus berasal dari rambut tubuh bagian ujung abdomen imago betina.

Tabel 4. Pengamatan Siklus Hidup Spodoptera litura dengan Perlakuan Ekstrak Lidah Mertua Kondisi Laboratorium

\begin{tabular}{|c|c|c|c|c|c|c|}
\hline \multirow[t]{2}{*}{ No. } & \multirow[t]{2}{*}{ Fase Hidup } & 0 & $200 \mathrm{ppm}$ & $400 \mathrm{ppm}$ & $600 \mathrm{ppm}$ & 800 ppm \\
\hline & & \multicolumn{5}{|c|}{ Hari } \\
\hline \multirow[t]{7}{*}{1.} & Larva & & & & & \\
\hline & Instar 1 & 3 & 3 & 3 & 3 & 3 \\
\hline & Instar 2 & 3 & 3 & 3 & 3 & 3 \\
\hline & Instar 3 & 3 & 4 & 4 & 4 & 4 \\
\hline & Instar 4 & 3 & 3 & $3-4$ & $3-4$ & 4 \\
\hline & Instar 5 & $2-3$ & 3 & 3 & $3-4$ & 5 \\
\hline & $\begin{array}{c}\text { Instar } 6 \\
\text { (Prapupa) }\end{array}$ & $2-3$ & 2 & 3 & 4 & 4 \\
\hline 2 & $\begin{array}{l}\text { Lama Siklus } \\
\text { hidup larva }\end{array}$ & $16-18$ & 18 & $18-20$ & $20-21$ & 23 \\
\hline 3. & Pupa & 7 & $8-9$ & $8-9$ & $\begin{array}{c}\text { Tidak } \\
\text { berubah }\end{array}$ & $\begin{array}{c}\text { Tidak } \\
\text { berubah }\end{array}$ \\
\hline 4. & Imago & 7 & $4-5$ & 5 & 0 & 0 \\
\hline 5. & Telur & 5 & $\begin{array}{c}\text { Tidak } \\
\text { menetas }\end{array}$ & $\begin{array}{c}\text { Tidak } \\
\text { menetas }\end{array}$ & 0 & 0 \\
\hline 6 & Total & $35-37$ & 0 & 0 & 0 & 0 \\
\hline
\end{tabular}


Dalam pengamatan rata-rata yang dibutuhkan telur untuk menetas membutuhkan waktu 5 hari sejak diletakkan oleh induknya, pada suhu $31-34^{\circ} \mathrm{C}$ pada kelembapan ruang $80-90 \%$. Telur yang dihasilkan imago dari perlakuan yang berhasil bertahan hidup, tidak menetas setelah kurang lebih sebulan lamanya ditunggu sejak diletakkan oleh imago. Hal ini sesuai dengan Syahputra, $d k k$., (2007) selain memiliki aktivitas insektisida, insektisida nabati juga memiliki aktivitas penghambat makan, penghambat pertumbuhan larva dan dapat menurunkan fekunditas imago sehingga menurunkan kesuksesan dalam telur menetas sehingga pemberian perlakuan berpengaruh terhadap kesuburan, kesuksesan dan lamanya telur menetas.

Pada Tabel 4 diketahui kelulusan hidup tertinggi terdapat pada perlakuan kontrol yaitu sebanyak $70 \%$ kemudian pada konsentrasi 200 ppm dan 400 ppm dengan 12,5\% selanjutnya pada 600 ppm sebanyak $10 \%$ dan terendah terdapat pada 800 ppm yaitu hanya $5 \%$. Hal ini sesuai dengan penelitian Utami (2010) dimana insektisida nabati akan memberikan efek residu secara signifikan sepanjang hidup serangga yang mengalami kecacatan karena paparan insektisida. Menurut Syahputra, $d k k$., (2007) selain memiliki aktivitas toksik, insektisida nabati juga memiliki aktivitas penghambat makan (antifeedant), penghambat pertumbuhan larva dan dapat menurunkan fekunditas imago.

Masa stadium pupa rata-rata membutuhkan 7 hari pada suhu $31-34{ }^{\circ} \mathrm{C}$ dengan kelembapan ruang $80-90 \%$. Jika dibandingkan dengan sesudah perlakuan S.litura memiliki waktu yang lebih panjang menuju imago yaitu 8-9 hari. Hasil yang dilaporkan Lestari, dkk., (2013) stadium pupa berkisar kurang lebih 10 hari. Balfas dan Willis (2009) melaporkan bahwa waktu yang diperlukan pupa menjadi imago berkisar 7-9 hari setelah diberi ekstrak berbagai macam tanaman. Menurut Lestari, dkk., (2013) siklus hidup S.litura yang menggunakan pakan buatan memiliki rata-rata lama hidup berkisar 16,72 sampai dengan 18,97 hari. panjang hidup larva memiliki pengaruh yaitu terjadinya panjang hidup yang lebih lama pada instar 4 hingg 5 hal ini dikarenkan larva mengalami peningkatan hormon juvenile sehingga tidak seimbang dengan produksi hormon eksdison.

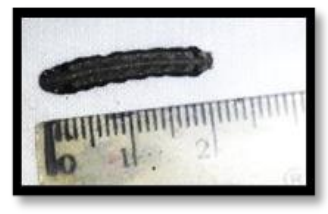

(a.)

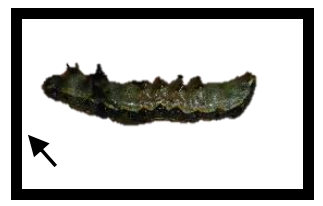

(c.)

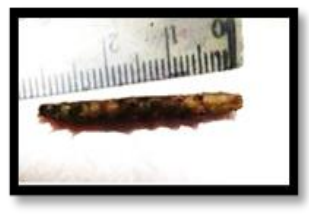

(b.)

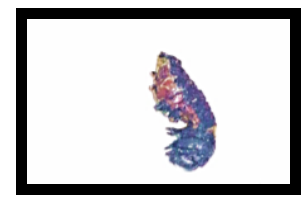

(d.)

Gambar 1. Larva S. litura: (a.) Normal, (b.), (c.) dan (d.). Setelah perlakuan (Dokumentasi Pribadi, 2020).

Rata-rata lama hidup imago berkisar 7 hari dengan makan atau tidak makan sama sekali. Menurut Murata and Tojo, (2002), apabila mengonsumsi gula cukup maka imago dapat terbang 
sangat jauh dan berumur panjang sehingga penyebaran telur bisa sampai pada target makanan untuk calon larva. Sedangkan jika dibandingkan dengan setelah perlakuan umur imago menjadi lebih pendek diakibatkan oleh imago yang mengalami penurunan nafsu makan atau sama sekali tidak mengonsumsi air gula yang disediakan.

Larva yang normal atau berada pada perlakuan kontrol berwarna terang dengan corak yang jelas dengan tubuh yang elastis dan kering, gerakan larva juga aktif dan cepat, aktivitas makan akan sangat cepat berbeda pada saat tahap imago dan bergerak sangat cepat terlebih lagi telah memasuki fase instar 3 (Gambar 4.1 bagian a). Larva akan terlihat mengurangi aktivitas makannya ketika memasuki instar 6 atau prapupa kemudian memasuki tisu atau mencari tempat yang gelap dan tidak akan berpindah tempat hingga tubuh mulai mengerut dan kutikula menjadi keras namun serangga akan tetap bereaksi apabila diberi rangsangan menandakan bahwa larva masih hidup fase instar 6 berlangsung paling lama 3 hari setelah itu pupa akan terbentuk. Apabila larva telah memiliki ciri-ciri kebalikan dibandingkan larva normal maka larva dinyatakan telah mengalami keracunan.

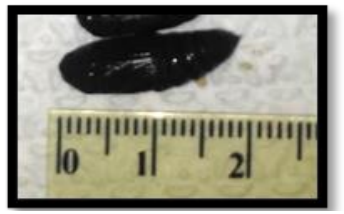

(a.)

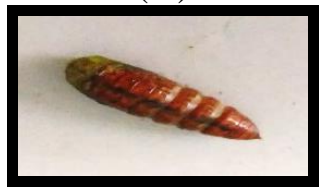

(c.)



(b.)

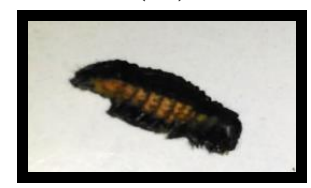

(d.)

Gambar 2. Pupa S. litura : (a.)Normal, (b.), (c.) dan (d.) Setelah perlakuan.

Hasil penelitian pada perlakuan terdapat perubahan aktivitas larva seperti larva menjadi lebih banyak diam melingkari tubuhnya dan hanya bergerak ketika dirangsang, larva banyak mengeluarkan cairan dari mulut sehingga permukaan tubuhnya menjadi licin dan beberapa bagian tubuhnya lembek karena umumnya larva mengeluarkan cairan melalui anus, beberapa perubahan lain, larva yang kebanyakan mengonsumsi makanan akan memiliki tubuh yang kaku hal tersebut bertentangan dengan kulit larva yang pada umumnya elastis, namun frekuensi mengonsumsi makanan pada larva yang diberi perlakuan cenderung normal, hal ini sesuai jika dibandingkan dengan Utami (2010) dimana ciri-ciri tersebut merupakan ciri-ciri larva yang terkena racun insektisida ditandai dengan tubuh larva menjadi kaku dengan berwarna lebih gelap cenderung hitam pada beberapa bagian tubuh kemudian apabila larva yang masih hidup memiliki karakter berjalan yang lamban dan tidak sensitif ketika diberi rangsangan.

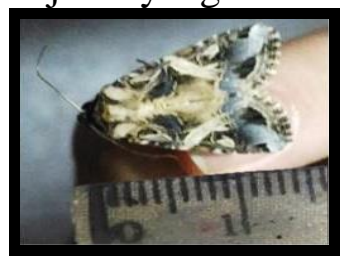

(a.)

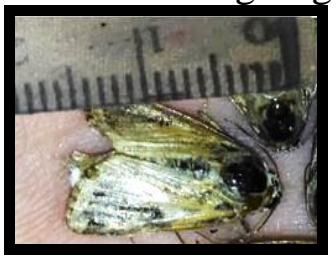

(b.)

Gambar 3. Imago S. litura: (a.) Normal, (b.) Setelah perlakuan 


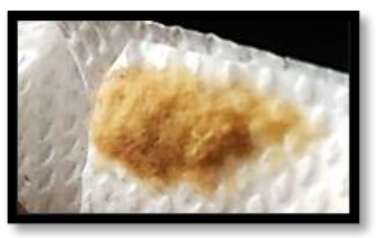

(a.)



(b.)

Gambar 4. Telur S. litura: (a.) Normal, (b.) Setelah perlakuan

Tanda-tanda morfologi pada larva yang mengalami keracunan memiliki tubuh yang kaku tidak lama akan terlihat tubuh larva mengeluarkan cairan berlebihan sehingga tubuh menjadi lunak dan hancur, beberapa larva yang mati hanya menyisakan kutikula kering (molting) ketika tubuhnya mengeluarkan cairan berlebihan tersebut. Pada bagian lateral tubuh larva yang umumnya bergaris putih pada sepanjang segmen tubuh berubah menjadi kemerahan dan mengerut di bagian tengah segmen abdomen, warna kutikula mulai menghitam dan tidak menampakkan corak yang jelas pada beberapa segmen hingga keseluruhan segmen menghitam pada tahap ini larva akan sangat sedikit menanggapi rangsangan hingga akhirnya larva mati (Gambar 4.1 bagian b). Hidayati, $d k k$., (2013), menyatakan bahwa senyawa tanin berfungsi sebagai zat astringen dengan menyusutkan jaringan dan menutup struktur protein pada kulit dan mukosa sehingga zat ini menghambat perkembangan yang menyebabkan jaringan kulit akan mengerut dan kering. Serangga yang mati tubuhnya mengering, warna menjadi hitam dan ukuran tubuh akan menyusut.

Pada larva yang berhasil hidup hingga mencapai tahap pupa kebanyakan pupa memiliki bentuk yang tidak normal dan berwarna hitam salah satunya pupa akan sangat pendek berkerut dan keras (Gambar 4.2 bagian b.) kemudian pupa menjadi keras dan tidak bergerak sehingga membusuk didalamnya. Pupa yang normal akan berwarna merah tua dan panjang rata-rata 20 mm, tidak memiliki kerutan dan sedikit lunak apabila ditekan. Menurut Effendi (2009), tandatanda morfologi pupa S.litura yang akan mati ditandai tubuh mengerut dan warna tubuh secara keseluruhan menjadi hitam, tidak menunjukkan rangsangan sehingga pada akhirnya mati.

Tabel 5. Pengamatan Kelulusan Hidup Larva Menjadi Pupa

\begin{tabular}{cccc} 
No. & Konsentrasi & $\begin{array}{c}\text { Larva-Pupa } \\
(\%)\end{array}$ & $\begin{array}{c}\text { Pupa- } \\
\text { Imago }(\%)\end{array}$ \\
\hline 1 & 0 & 77,5 & 70 \\
\hline 2 & $200 \mathrm{ppm}$ & 12,5 & 7,5 \\
\hline 3 & $400 \mathrm{ppm}$ & 12,5 & 5 \\
\hline 4 & $600 \mathrm{ppm}$ & 10 & 0 \\
\hline 5 & $800 \mathrm{ppm}$ & 5 & 0 \\
\hline
\end{tabular}

Beberapa pupa hidup hingga mencapai fase imago memiliki ciri sayap yang mengerut dan tidak dapat keluar dari pupa dan beberapa lagi memiliki sayap dengan corak yang pudar (Gambar 3 bagian b), beberapa yang normal berhasil melakukan perkawinan namun telur yang dihasilkan tidak dapat menetas berwarna pucat dan menghitam (Gambar 2. bagian b). Menurut Sa'diyah, $d k k$., (2013) tanda-tanda tersebut berdasarkan gangguan pada saat ekdisis pada serangga. Ekdisis atau ganti kulit diperlukan serangga tidak hanya untuk tumbuh melainkan juga untuk mencapai tahap dewasa sehingga dapat berkembang biak apabila hormon juvenil terus diproduksi maka 
hormon eksdison tidak dapat diproduksi sehingga imago akan mati atau mengalami morfologi abnormal.

Berdasarkan pengamatan perkembangan siklus ulat grayak yang dilakukan di Laboratorium di sajikan pada Tabel 5. Pada tanaman lidah mertua mengandung senyawa flavonoid, alkaloid, tannin, saponin dan triterpenoid yang menyebabkan kematian dan keracunan pada ulat grayak, sehingga diperoleh persentase mortalitas paling tinggi yaitu 63,6\% pada konsentrasi tertinggi 800 ppm selama 72 jam dan tertinggi kelulusan hidupnya adalah konsentrasi kontrol pada pupa sebanyak 77,5\% dan padaimago sebesar $70 \%$ Berdasarkan hasil pengamatan pada setiap konsentrasi menunjukkan bahwa semakin meningkatnya konsentrasi dan waktu perlakuan maka akan meningkatkan persentase kematian larva. Menurut Prabowo (2010) semakin meningkatnya konsentrasi yang digunakan maka racun perut yang masuk ke dalam tubuh akan semakin banyak sehingga larva akan semakin banyak yang mengalami keracunan yang memiliki tipe racun perut dan menghambat pencernaan larva. Racun perut akan mempengaruhi metabolisme larva setelah memakan racun, kemudian racun akan masuk ke dalam tubuh dicerna dalam saluran tengah (midgut) yang kemudian diedarkan bersama darah.

\section{SIMPULAN}

Dari hasil penelitian yang telah dilakukan, maka dapat disimpulkan bahwa ekstrak etanol tanaman lidah mertua ( $S$. trifasciata Prain) terhadap mortalitas $S$. litura, mortalitas tertinggi adalah $63,6 \%$ pada konsentrasi 800 ppm dan nilai mortalitas terendah 36,4\% dengan konsentrasi 200 ppm selama 72 jam yang termasuk kedalam toksisitas sedang. Ekstrak etanol tanaman lidah mertua memiliki aktivitas toksik dengan besar nilai LC50, 72 jam adalah 562,9 ppm. Masa hidup rata-rata ulat grayak sebanyak 35-37 hari dalam satu siklus pada skala laboratorium (tanpa perlakuan).

\section{DAFTAR RUJUKAN}

Agustina E.P., Fauzana, H., dan Sutikno, A.. (2017). Pengaruh Penambahan Surfaktan Dalam Ekstrak Daun Sirih Hutan (Piper Aduncum L.) Untuk Mengendalikan Ulat Grayak (Spodoptera litura F.)Pada Tanaman Kedelai (Glycine max (L.) Merril). Jurnal OM Faperta $U R, 4(1)$.

Azmir, J. and Sarker M.Z.I. (2013). Techniques for extraction of bioactive compound frrom plant material. Journal of Food Engineering, 117(4): 2-3.

Balfas, R. dan Willis, M. (2009). Pengaruh Ekstrak Tanaman Obat Terhadap Mortalitas Dan Kelangsungan Hidup Spodoptera litura F. (Lepidoptera, Noctuidae). Buletin Littro, 20 (2).

Berame, S.C., Diana R.P.C., Marycris L., and Manaban, J.S. (2017). Preliminary Phytochemical Screening and Toxicity Test of Leaf and Root Parts of the Snake Plant (Sansevieria trifasciata). Journal of Phylogenetics \&Evolutionary Biology, 5 (3): 3.

Cahyono, B. (2003). Teknik dan Strategi Budidaya Sawi Hijau (Pai-Tsai). Yogyakarta: Yayasan Pustaka Nusantara.

Djunaedy, A., dan Anggrahini, N. (2018). Efektivitas Ekstrak Daun, Biji Dan Kulit Batang Mahoni (Swietenia mahagoni Jacq) Terhadap Ulat Grayak (Spodoptera litura F.) Jurnal Inisiasi, 7 (2).

Effendi, R. (2009). Ekstraksi dan Identifikasi Senyawa Katekin dari Gambir. Jurnal Fundamental dan Aplikasi Teknik Kimia, 4(3):85-89. 
Fattah, A. dan Ilyas, A. (2016). Siklus Hidup Ulat Grayak (Spodoptera litura, F) dan Tingkat Seranganpada Beberapa Varietas Unggul Kedelai di Sulawesi Selatan. Prosiding Seminar Nasional Inovasi Teknologi Pertanian Banjarbaru.

Fuadzy, H., Hodijah, D.N., dan Jajang A. (2010). Kerentanan Larva Aedes aegypty Terhadap Temepos Ditiga Kelurahan Endemis Demam Berdarah Dengue Kota Suka Bumi. Buletin Penelitian Kesehatan. 43(1): 44.

Haryanti, S., Suryana M., dan Nurrahmad. (2006.) Uji Daya Insektisida Ekstrak Etanol 70\% Biji Buah Mahkota Dewa Terhadap Ulat Grayak (Spodoptera litura Fab.) Instar Dua.

Hasyim, A., Wiwin S., Luluk S.M., Liferdi L., dan Abdi H. (2017). Bioaktivitas Enam Ekstrak Tumbuhan untuk Pengendalian Hama Tungau Kuning Cabai Polyphagotarsonemus latus Banks(Acari: Tarsonemidae) di Laboratorium. Jurnal Hortikultura, 27 (2):5-6.

Hasyim, A., Setiawati, W., Lukman, L., dan Marhaeni, L.S. (2019). Evaluasi Konsentrasi Lethal dan Waktu Lethal Insektisida Botani Terhadap Ulat Bawang (Spodoptera exigua) di Laboratorium. Jurnal Hortikultura, 29(1)1.

Hidayati, N.N., Yuliani, Kuswanti, N. (2013). Pengaruh Ekstrak Daun Suren Terhadap Mortalitas dan Aktivitas Makan Ulat Daun pada Tanaman Kubis. Universitas Negeri Surabaya. Jurnal Unesa LenteraBio, 2 (1):95-99.

Iinnaninengseh dan Ayuswastika, J. (2017). Respon Pertumbuhan Tanaman Lidah Mertua (Sansevieria Sp) Yang dibudidaya Pada Jenis Media Tanam Tanah Berbeda Dengan Pemberian Pupuk Bokashi Hijauan Daun Kudo. Jurnal Ilmu Pertanian Universitas Al Asyariah, 2(2):67.

Komala, O., Yulia, I., dan Pebrianti R. (2012). Uji Efektivitas Ekstrak Etanol Daun Lidah Mertua (Sansevieria trifasciata Prain) Terhadap Khamir Candida albicans. Jurnal Fitofarmaka, 2(2).

Lestari, S., Ambarningrum, T.B., dan Pratiknyo, H. (2013). Tabel Hidup Spodoptera litura Fabr. dengan Pemberian Pakan Buatan yang Berbeda. Jurnal Sain Veteriner, 31(2): 166-179.

Nihayah, A., Ginanjar, A., dan Sopyan, T. (2016). Pengaruh Ekstrak Etanol Cabai Merah (Capsicum Annuum L.) Terhadap Mortalitas Hama Ulat Grayak (Spodoptera litura F.). Jurnal Pendidikan Biologi (Bioed), 1(1).

Marwoto dan Suharsono. (2008). Strategi Dan Komponen Teknologi Pengendalian Ulat Grayak (Spodoptera litura Fabricius) Pada Tanaman Kedelai. Jurnal Litbang Pertanian, 27 (4):131136.

Murata, M and Tojo, S. (2002). Utilization of lipid for flight and reproduction in Spodoptera litura (Lepidoptera: Noctuidae). European Journal of Entomology, 99(2): 4.

Prabowo, H. (2010). Pengaruh Ekstrak Daun Nerium oleander L. terhadap Mortalitas dan Perkembangan Hama Spodoptera litura Fab. Jurnal Biota, 15 (3):426.

Prawesti, D.I. (2017). Fektivitas Ekstrak Daun Kembang Bulan (Tithonia Diversifolia (Hemsley) A. Gray) Sebagai Pestisida Nabati Pengendalian Hama Crocidolomia Binotalis Pada Tanaman Sawi (Brassica juncea L.). Jurnal Prodi Biologi, 6(8): 2-3.

Rifai, M., Hasriyanty dan Nasir, N. (2016). Efikasi Dua Jenis Ekstrak Tumbuhan dan Kombinasi KeduanyaTerhadap Mortalitas Hama Ulat Bawang Merah Spodoptera exigua Hubn.(lepidoptera:noctuidae). Jurnal Agrotekbis, 4 (2). 
Risqa, S. (2018). Uji efektifitas ekstrak daun (Mirabilis jalapa L.) terhadap mortalitas larva instar III (Spodoptera litura F.) Dalam kondisi Laboratorium. Skripsi. Fakultas Matematika dan Ilmu Pengetahuan Alam. Universitas Mulawarman.

Roy, J., Kudus, M., and Begum, B. (2012). Evaluation of Analgesic, Cytotoxic, and Antioxidant Activities of Sansevieria roxbrghiana Schult. And Schult. f., Asian Pasific Journal of Tropical Biomedicine, 1(1): 723-726.

Sa'diyah N.A., Purwani K.I., dan Wijayawati L. (2013). Pengaruh ekstrak daun bintaro (Cerbera odollam) terhadap perkembangan ulat grayak (Spodoptera litura F). Jurnal Sains dan Seni Pomits, 2(2): 2337-3520.

Samsudin. (2008). Virus Patogen Serangga: Bio-Insektisida Ramah Lingkungan. (Online), (http://www.pertaniansehat.or.id, 01 November 2019).

Syahputra, E., Manuwoto, S., Darusman, L.K., Dadang, dan Prijono, D. (2004). Aktivitas insektisida bagian tumbuhan Calophyllum soulattri Burm. f. (Clusiaceae) terhadap larva Lepidoptera. Jurnal HPT Tropika, 4(1):23-31.

Syahputra, E., Prijono, D., dan Dono, D. (2007). Sediaan Insektisida Calophyllum soulattri: Aktivitas Insektisida Dan Residu Terhadap Larva Crocidolomia Pavonana Dan Keamanan Pada Tanaman. Jurnal HPT Tropika, 7(1):13-22.

Usman, N., Saleh E.J., dan Nusi M. (2019). Kandungan Acid Detergent Fiber dan Neutral Detergen Fiber Jerami Jagung Fermentasi dengan menggunakan Jamur Trichoderma viride dengan Lama Inkubasi Berbeda. Jambura Journal of Animal science, 1(2):58.

Utami, S. (2010.) Aktivitas Insektisida Bintaro (Cerbera odollam Gaertn) Terhadap Hama Eurema sp. pada Skala Laboratorium. Jurnal Penelitian Hutan Tanaman, 7(1):211-220. 